\title{
Effect of diel and interday variations in light on the cell division pattern and in situ growth rates of the bloom-forming dinoflagellate Heterocapsa triquetra
}

\author{
R. W. Litaker ${ }^{1,2, *}$, V. E. Warner ${ }^{3}$, C. Rhyne ${ }^{3}$, C. S. Duke ${ }^{4}$ B. E. Kenney ${ }^{5}$, J. Ramus ${ }^{5}$, P. A. Tester ${ }^{1}$ \\ ${ }^{1}$ Center for Coastal Fisheries and Habitat Research, National Ocean Service, NOAA, 101 Pivers Island Road, Beaufort, \\ North Carolina 28516, USA \\ ${ }^{2}$ Program in Molecular Biology and Biotechnology, CB\#7100, 442 Taylor Hall, University of North Carolina, Chapel Hil, \\ North Carolina 27599, USA \\ ${ }^{3}$ School of Science and Technology, PO Box 18540, 1400 J. R. Lynch Street, Jackson State University, \\ Mississippi 39217-1050, USA \\ ${ }^{4}$ The Environmental Company, Inc., 1611 N. Kent Street, Suite 900, Arlington, Virginia 22209, USA \\ ${ }^{5}$ Marine Laboratory, Nicholas School of the Environment and Earth Sciences, Duke University, 135 Duke Marine Lab Road, \\ Beaufort, North Carolina 28516, USA
}

\begin{abstract}
Heterocapsa triquetra is an important bloom-forming dinoflagellate found in estuaries and nearshore regions worldwide. In an initial time-intensive study, the shallow, tidally mixed Newport River estuary, North Carolina, USA, was sampled from a fixed point located in the middle of the estuary every $2 \mathrm{~h}$ for $2 \mathrm{wk}$ during the development of an $H$. triquetra bloom. The objective of this study was to investigate how short-term, high-frequency changes in temperature, light and salinity affected diel and interday cell division patterns and in situ growth rates of $H$. triquetra. During this study, phytoplankton samples were preserved in buffered formaldehyde and mitotic indices determined by acridine orange staining. The diel division pattern showed a nocturnal maximum between 23:00 and 05:00 $\mathrm{h}$ with reduced division during the day, a pattern characteristic of most dinoflagellates. The relative proportion of binucleate cells present during the day was influenced by interday variations in total irradiance, increasing during 2 of the 3 periods when there were 3 or more consecutive high light days (>28 $\mathrm{E} \mathrm{m}^{-2} \mathrm{~d}^{-1}$ ). Approximately $40 \%$ of the overall variation in interday division rates could be accounted for by differences in daily irradiance. The interday light differences were largely due to well-developed atmospheric frontal systems that brought increased cloud cover to the study area at regular 3 to 4 d intervals. The initial study, however, was of insufficient length to determine if the transient day-to-day light limitation could significantly affect seasonal bloom formation. A second longer-term, spatially intensive study was therefore undertaken to assess the relative importance of the incident light levels and nutrient inputs in controlling $H$. triquetra bloom initiation. During the second study, the estuary was monitored for photosynthetically active radiation (PAR), salinity, temperature, inorganic nutrients and cell densities of $H$. triquetra at 9 locations every wk from 23 December 1997 to 27 March 1998. Maximal $H$. triquetra bloom formation occurred during a 2 wk period when daily incident light levels were at or near the annual low. This suggested that $H$. triquetra is well adapted for utilizing low light levels and that variation in in situ growth rates in response to daily changes in PAR had little effect on bloom development. Instead, bloom initiation began with inputs of nitrogen-rich water following a runoff event, indicating that nutrient inputs are much more important in controlling bloom development than is light.
\end{abstract}

KEY WORDS: Heterocapsa triquetra $\cdot$ Cell division · Mitotic index · Diel $\cdot$ Light · Dinoflagellate · Bloom development 


\section{INTRODUCTION}

The dinoflagellate Heterocapsa (= Peridinium) triquetra forms intense blooms in coastal and estuarine regions throughout the world (Kim 1997, Kononen et al. 1999, Lindholm \& Nummelin 1999). These blooms typically reach $\sim 2$ to $10 \times 10^{6}$ cells $\mathrm{l}^{-1}$, but can reach densities as high as $1 \times 10^{8}$ cells ${ }^{-1}$ (Braarud \& Pappas 1951, Pieterse \& Van der Post 1967, Stanley \& Daniel 1985). In North Carolina estuaries, H. triquetra blooms generally occur in winter when day lengths are relatively short, and well-organized atmospheric frontal systems bring cloudy conditions that significantly reduce incident irradiance for 1 to $3 \mathrm{~d}$ periods (Kuenzler et al. 1977, 1979). These atmospheric frontal systems are associated with regular rainfall and runoff events that lower the salinity of the estuary and input nutrients. Ambient water temperature changes of 3 to $6^{\circ} \mathrm{C}$ also accompany these frontal systems (Litaker et al. 1987). How temperature, salinity, and light affect the growth of dinoflagellates has been examined in a number of culture studies. However, relatively few studies have considered how concurrent environmental changes, such as those associated with the passage of atmospheric frontal systems, affect dinoflagellate growth in the field. Hence, a time-intensive field study was undertaken in February 1983 to examine how simultaneous hourly changes in light, salinity and temperature were correlated with changes in the in situ growth rates of $H$. triquetra.

This study spanned a $14 \mathrm{~d}$ period during the onset and development of a bloom. The observed in situ growth rates were compared to those predicted from culture studies on the effects of light, salinity, and temperature on Heterocapsa triquetra growth. Quantifying in situ growth rates, and knowing which factors control them, is often essential for assessing and interpreting phytoplankton population dynamics (Jacquet et al. 2001). For example, greater accumulation of cells than can be accounted for based on in situ growth rates indicates that behavioral or physical concentration processes are at work. Similarly, population densities that are lower than expected based on in situ growth rates indicate losses due to dilution, grazing or other causes. Without knowing the in situ growth rates, these lossand-gain factors would be difficult to quantify.

Results from the 1983 time intensive study indicated that of the factors investigated, only light was significantly correlated with diel and interday changes in in situ growth rates. The 1983 study, however, was too short to determine if the interday effects of light on in situ growth rates were sufficient to influence the overall rate of bloom formation. The fixed-point sampling regime employed in the 1983 study also made it difficult to assess the effects of nutrient loading on in situ growth rates. The reason was that nutrients entering the estuary from the Newport River were generally taken up before they reached the fixed-point sampling site. As a result, variations in nutrient supply could not be estimated and compared with changes in in situ growth rates. Thus, to better understand how week-to-week changes in light, salinity, temperature, and inorganic nutrient loading affected bloom development, a second study was undertaken. Samples were collected weekly at 9 fixed stations along the axis of the estuary from late December 1997 through March 1998. Samples from the freshwater portion of the Newport River, the primary source of nutrients to the estuary during winter, allowed nutrient inputs to be estimated. Net growth rates of Heterocapsa triquetra were estimated from week-to-week changes in average cell densities. These net growth rates were compared with in situ growth rates from the 1983 time intensive study and maximal growth rates available from published studies using cultures.

\section{MATERIALS AND METHODS}

Study site. All studies were carried out in the Newport River estuary, North Carolina, USA. This $27 \mathrm{~km}^{2}$ estuary is shallow (average depth $1 \mathrm{~m}$ ) and well mixed (Litaker et al. 1987). Residence times for the entire estuary vary from 7 to $45 \mathrm{~d}$ depending on the flow of the Newport River (Hyle 1976). The middle portion of the Newport River estuary is relatively wide compared to the upper or lower sections of the estuary. With the exception of very dry periods when runoff is exceedingly low, water entering the wider, shallower middle section of the estuary from the Newport River creates a mesohaline frontal zone. The location of this frontal zone shifts farther down the estuary as flow increases. Relative phytoplankton retention times in the frontal zone vary with flow, but are generally longer than in the river-flushed uppermost portions of the estuary or in the tidally flushed lower estuary.

Time intensive study of how bihourly changes in light, salinity, and temperature affect in situ growth rates during bloom initation (1983). During this study, a station located in the geographic middle of the estuary $\left(33^{\circ} 46.2^{\prime} \mathrm{N}, 76^{\circ} 43^{\prime} \mathrm{W}\right)$ was monitored bihourly from 30 January to 13 February 1983. Salinity (psu as conductivity) and water temperature were determined using an Industrial Instruments RS-5-2 salinometer. Photosynthetically active radiation (PAR, ME $\mathrm{m}^{-2} \mathrm{~s}^{-1}$ ) was determined with a LI-COR 192 S sensor attached to a recording integrator. Secchi depth (SD) was measured using a $0.3 \mathrm{~m}$ Secchi disk attached to a marked pole. Attenuation coefficients $(k)$ were calculated from the $\mathrm{SD}$ and the relationship $k=1.35 / \mathrm{SD}$, determined 
empirically from simultaneous SD and light attenuation measurements. Average light levels in the water column were calculated by the method of Riley (1957). Cumulative daily PAR was determined by summing the average hourly water column fluxes. Water samples were collected at mid-depth, which was between 0.4 and $1.2 \mathrm{~m}$ depending on tidal cycle. Chl $a\left(\mu g \mathrm{l}^{-1}\right)$ was determined by fluorometric analysis (Turner Design III fluorometer) of particulate material collected by gentle suction onto glass fiber filters (Gelman A/E) and extracted into $90 \%$ acetone (Yentsch \& Menzel 1963).

The mitotic index (MI) was determined from bihourly water samples taken from 30 January to 13 February 1983. From mid-depth, $20 \mathrm{l}$ of water were removed using a pump and then filtered through a $20 \mu \mathrm{m}$ mesh net. The approximately $250 \mathrm{ml}$ of the sample contained in the cod end of the net were preserved in buffered formaldehyde. The MI was determined by acridine orange staining of the preserved cells and by counting the number of binucleate cells in the population using epifluorescence microscopy. In all but 3 samples, the MI was estimated by examining 250 cells. The remaining 3 samples were collected on ebb-tides where the numbers of Heterocapsa triquetra were too low to obtain 250 cells. In these 3 instances, the MI was estimated by averaging the surrounding bihourly values.

Minimum daily growth rates were estimated using the formula:

$$
\ln \left(1+f_{\max }\right)
$$

where $f_{\max }$ is the maximal MI value during a $24 \mathrm{~h}$ period (McDuff \& Chisholm 1982). Daily growth rates were also estimated from a modification of the McDuff \& Chisholm equation:

$$
\mu=1 / N \cdot t_{\mathrm{d}} \sum_{\mathrm{i}=1}^{\mathrm{N}} \ln \left(1+f_{\mathrm{i}}\right)
$$

where $\mu$ specific growth rate $\left(\mathrm{d}^{-1}\right), t_{\mathrm{d}}=$ duration of the terminal event (usually defined as time to pass through $\left.\mathrm{G}_{2}+\mathrm{S}+\mathrm{M}\right), \mathrm{N}=$ number of sampling periods $\mathrm{d}^{-1}$, and $f_{\mathrm{i}}$ is the mitotic index for sampling period i. Sensitive microfluorometry techniques make it possible to identify $\mathrm{S}+\mathrm{G}_{2}+\mathrm{M}$ phase cells by their higher DNA content. Using these microfluorometry techniques, $t_{\mathrm{d}}$ can be estimated in populations where cell division is to some degree synchronized. This is accomplished by monitoring changes in the relative proportion of $\mathrm{G}_{1}$ to $\mathrm{S}+\mathrm{G}_{2}+\mathrm{M}$ phase cells through time and applying deconvolution techniques to establish the length of the terminal event (Whitely et al. 1993, Gisselson 1999). In this study, the method employed was less sensitive and only capable of detecting M phase cells. Hence, the MI was defined here as the proportion of binucleate cells in the popu- lation at each sampling period and the terminal event $t_{\mathrm{d}}$ as the time between the formation of 2 distinct nuclei and the time when the dividing cells separate. Though less sensitive, the binucleate approach used in this study has the advantage of being applicable to samples where detrital material, typical of many estuaries, makes sorting of cells impossible, or when internal cell structures obscure the fluorescent signal from the nucleus, particularly during the $\mathrm{S}$ and $\mathrm{G}_{2}$ phase.

Eq. (2) assumes a constant, known $t_{\mathrm{d}}$. Though there are no direct estimates of $t_{\mathrm{d}}$ for Heterocapsa triquetra in the field, a $t_{\mathrm{d}}$ value can be approximated from laboratory studies of $H$. triquetra grown at an average daily temperature of $13.5^{\circ} \mathrm{C}$ (Chang \& Carpenter 1988). In these studies, both stationary and exponentially growing cells were stained with a DNA-specific fluorescent dye and the changes in DNA content followed using a sensitive microfluorometry system. Cells destined to divide on any given day underwent DNA synthesis, then moved into $G_{2}$ sometime during either the light period or the first half of the dark period. The $G_{2}$ population peaked during the middle of the dark period at which time the cells began entering mitosis. With the onset of mitosis, the $\mathrm{G}_{2}+\mathrm{M}$ population began declining. The decline continued for 8 to $10 \mathrm{~h}$ after the peak was reached. Upon completing mitosis, newly divided cells quickly moved into synthesis (S) phase. Thus the decline in the $\mathrm{G}_{2}+\mathrm{M}$ population was matched by a corresponding increase in the $\mathrm{S}$ phase population. These data indicate that at $13.5^{\circ} \mathrm{C}$, the binucleate cells, which had clearly entered mitosis, likely had finished cell division in $8 \mathrm{~h}$ or less $\left(t_{\mathrm{d}} \leq 8 \mathrm{~h}\right)$. Therefore, using this $t_{\mathrm{d}}$ value, and the bihourly MI values, we were able to obtain a daily growth rate estimate using Eq. (2). Because not all cells required the full $8 \mathrm{~h}$ to divide, using a $t_{\mathrm{d}}$ value of $8 \mathrm{~h}$ likely underestimated the true division rate found in the field.

Daily growth rates calculated using Eq. (2) integrated the MI values between 07:00 $\mathrm{h}$ one morning and 05:00 $\mathrm{h}$ the next morning to reflect any influence of the previous day's light levels on the following night's cell division rate. The maximum growth rates were also estimated by calculating daily water temperatures and a plot of the maximum growth rates of Heterocapsa triquetra at different temperatures derived from non-nutrient limited culture studies (Braarud \& Pappas 1951, Yamochi 1984, Anderson \& Stolzenbach 1985, Chang \& Carpenter 1988).

The MI time series was subjected to spectral analysis as described in Litaker et al. (1987). Spectral analysis provides a means of partitioning the total variation in a time series into dominant periodicities. The total number of harmonics into which the data can be partitioned is proportional to the length of the data set. The data are plotted from low frequency, i.e. longer time 
periods, to high frequency. The spacing of the harmonics into which the variation is divided increases proportionately to frequency. As a result, resolution at the lower frequencies is less than at the higher frequencies. The lowest frequencies go from the infinite period, which represents the overall trend in the data set, to weekly, biweekly, daily, and so on for the higher frequencies.

The amount of variation in minimal daily growth rates estimated using Eq. (1) accounted for by average daily light, salinity, and temperature was estimated by analysis of variance without replication (Sokal \& Rohlf 1994). Changes in short-term nutrient input, particularly nitrogen, are also likely to affect growth, given that phytoplankton in the Newport River are generally N-limited. This input, however, could not be addressed due to the fact that the nutrients entering the estuary via runoff were generally taken up before reaching the sampling station. Hence, the nutrient levels were generally below the current levels of detection and could not be used as part of the multiple regression analysis. The effects of nutrient loading were instead assessed in a second study described below.

Spatially intensive study to determine the effects of week-to-week variations in light and nutrient inputs on Heterocapsa triquetra bloom formation (1997-1998). During this spatially intensive study, the estuary was sampled at 9 locations every wk for a 3 mo period from 23 December 1997 to 27 March 1998 (Litaker et al. 2002 this volume). Surface rather than mid-depth water samples were collected because no significant stratification in any of the parameters measured during the 1983 study was observed in this shallow tidally mixed estuary. A subsample $(\sim 125 \mathrm{ml})$ was taken at each station, preserved with Utermöhl's solution (Guillard 1973), and kept tightly capped in dark bottles. A total of 103 preserved samples were counted for the presence of the dinoflagellate Heterocapsa triquetra at either 100 or $200 \times$ using an inverted Wild microscope (Lund et al. 1958). Chl $a$, salinity, water temperature, and PAR were determined for each station as described previously (Litaker et al. 2002).

Average weekly Heterocapsa triquetra cell densities were determined by averaging the cell concentrations at all stations where significant numbers of $H$. triquetra were present. This region generally covered about 40 to $60 \%$ of the estuary. Net daily growth rates were calculated using [ln(average cell density week $\left.\mathrm{w}_{t+1}\right) / \mathrm{ln}$ average cell

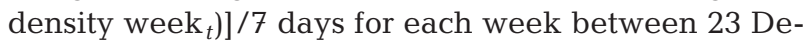
cember 1997 to 6 March 1998. Changes in net growth rates were then compared to changes in temperature,

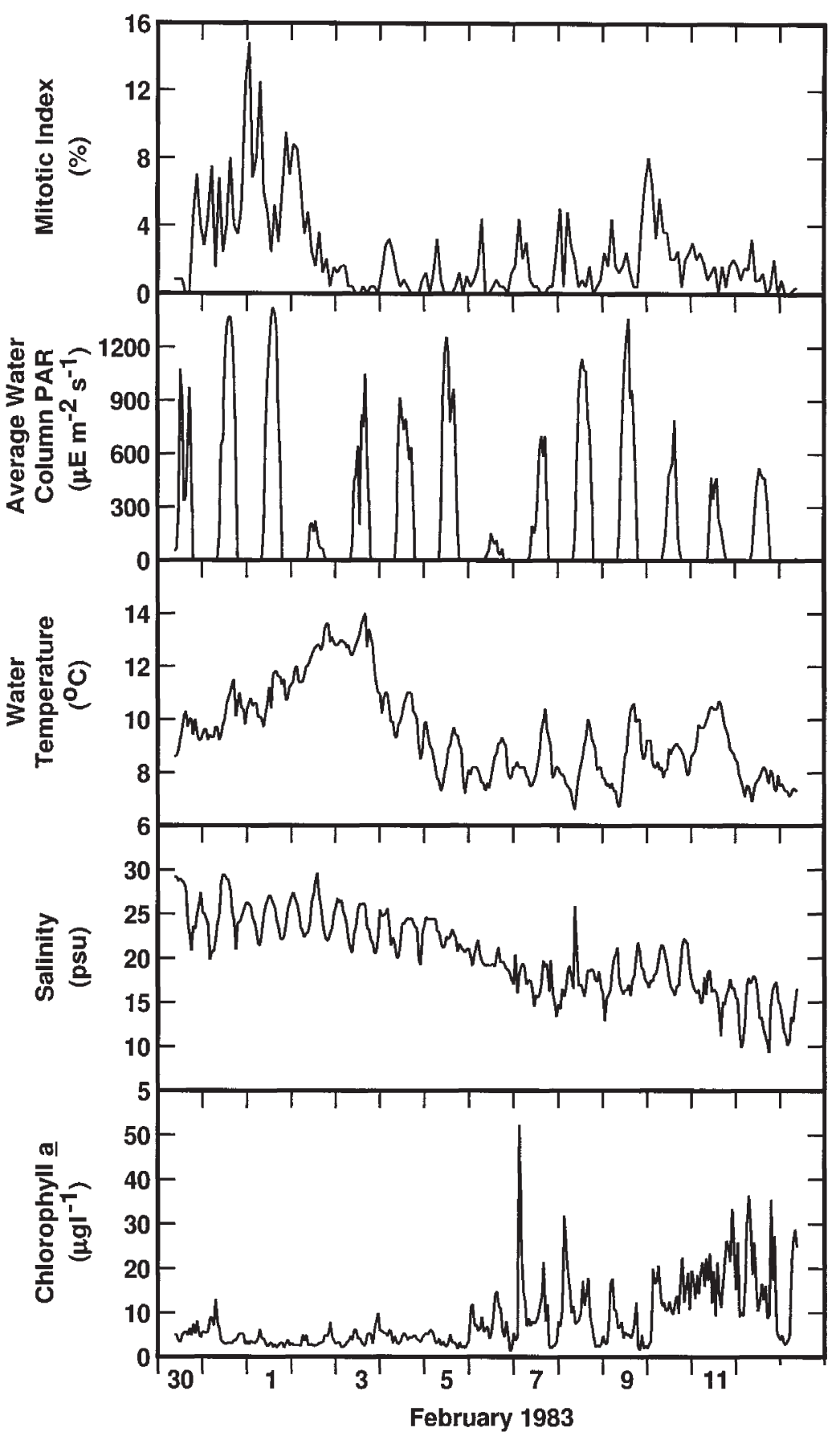

Fig. 1. Time series for mitotic index (MI) as \% of binucleate Heterocapsa triquetra cells in the population, average water column photosynthetically active radiation (PAR) $\left(\mu \mathrm{E} \mathrm{m} \mathrm{m}^{-2} \mathrm{~s}^{-1}\right)$, water temperature $\left({ }^{\circ} \mathrm{C}\right)$, salinity (psu), and chl $\mathrm{a}\left(\mu \mathrm{g} \mathrm{l}^{-1}\right)$ from 30 January to 13 February 1983. Incident light levels on 28 to 29 January 1983, the 2 days preceding the study period, were comparable to those on 1 February 
salinity, light, and inorganic N loading. Inorganic N loading was estimated by multiplying the flow rate of the river by the average river concentrations of $\mathrm{N}$ in the form of nitrate, nitrite, and ammonia. The weekly flow rates of the Newport River were determined using the following regression equation based on existing salinities and flow rate measurements (Litaker 1986): flow $\left(\mathrm{m}^{3} \mathrm{wk}^{-1}\right)=$ $\left(0.0134 X^{2}-1.5143 X+35\right) \times 6.05 \times 10^{5}, \mathrm{R}^{2}=0.946$ where $X=$ salinity (psu) measured at the sampling station.

\section{RESULTS}

\section{Time-intensive study (1983)}

Though variable from day to day, the diel division cycle showed a distinct pattern with a maximum number of binucleated cells in the middle of the dark period and a minimum during the middle of the light period (Figs. $1 \& 2$ ). This diel cycle shows up as a small but distinct signal at the $24 \mathrm{~h}$ periodicity in the spectral analysis (Fig. 3). A majority of the variation, however, partitions into the lower frequencies for periods $>2 \mathrm{~d}$. Partitioning of the variation into longer periodicities reflect the large interday changes in the MI seen in Fig. 1.

The minimal daily growth rates estimated using Eq. (1) and the MIs measured during the 1983 study ranged from 0.02 to $0.14 \mathrm{~d}^{-1}$. These specific growth rates are lower than the maximum potential growth rates of between 0.037 and $0.23 \mathrm{~d}^{-1}$ estimated from laboratory studies on non-nutrient-limited Heterocapsa triquetra growth over the range of temperatures observed in this study (Fig. 4, Table 1). The daily growth rates estimated using Eq. (2), and with $t_{\mathrm{d}}=8 \mathrm{~h}$, were generally equivalent to, or slightly higher than, those obtained using Eq. (1). The relative agreement between the 2 methods indicates that a $t_{\mathrm{d}}$ value of $8 \mathrm{~h}$ estimated from laboratory experiments represents a reasonably conservative estimate for the time binucleate $H$. triquetra cells measured in this study require to divide.

The large interday variations in daily growth rates using Eq. (1) were significantly correlated ( $p<0.05$, unadjusted $\mathrm{R}^{2}=0.43$ ) with interday variations in total daily PAR available in the water column, and to a much lesser extent, salinity (Figs. 1 \& 5, Table 2). The daily growth rates of Heterocapsa triquetra increased during 2 periods between Days 1 and 3, and 10 and 11 of the study when total daily water column irradiances were $>28 \mathrm{E} \mathrm{m}^{-2} \mathrm{~d}^{-1}$ (Fig. 1, Table 1). In contrast, a similar high light period on Days 6 and 7 of the study, when total daily irradiances were $>29 \mathrm{E} \mathrm{m}^{-2} \mathrm{~d}^{-1}$, did not cause growth rates to increase measurably. This high light period, however, coincided with a sudden decrease in water temperature, which may have adversely affected growth rates.

During the 2 high light periods when growth did increase, the proportion of binucleate cells increased during the day to $\sim 5$ to $15 \%$ of the preceding nocturnal maximum. There were also no times during the day when binucleate cells were absent from the samples. In contrast, on the low light days the number of binucleate cells was lower throughout the day and there was generally a period sometime between noon and mid-afternoon when binucleate cells were not found (Figs. 1 \& 2).

Heterocapsa triquetra blooms in the Newport River estuary typically take 2 to $3 \mathrm{wk}$ to develop (Fig. 1). The center of the bloom is located in a mesohaline frontal zone that develops in the middle section of the estuary when wintertime runoff from the Newport River is high. The actual location of this frontal zone moved farther down the estuary during the course of the study as flow increased. The frontal zone also shifts position over a tidal cycle. The number of $H$. triquetra cells was greatest in the mesohaline frontal zone and decreased to either side of that zone (Figs. 1 \& 6). During the first part of the time intensive study, samples were taken from the high salinity population at the downstream edge of the main bloom ( $\mathrm{chl} a<10 \mu \mathrm{g} \mathrm{l}^{-1}$ ). As runoff increased following rainfall events, the central portion of the intensifying bloom was displaced toward the fixed sampling site. Toward the latter part of the study,

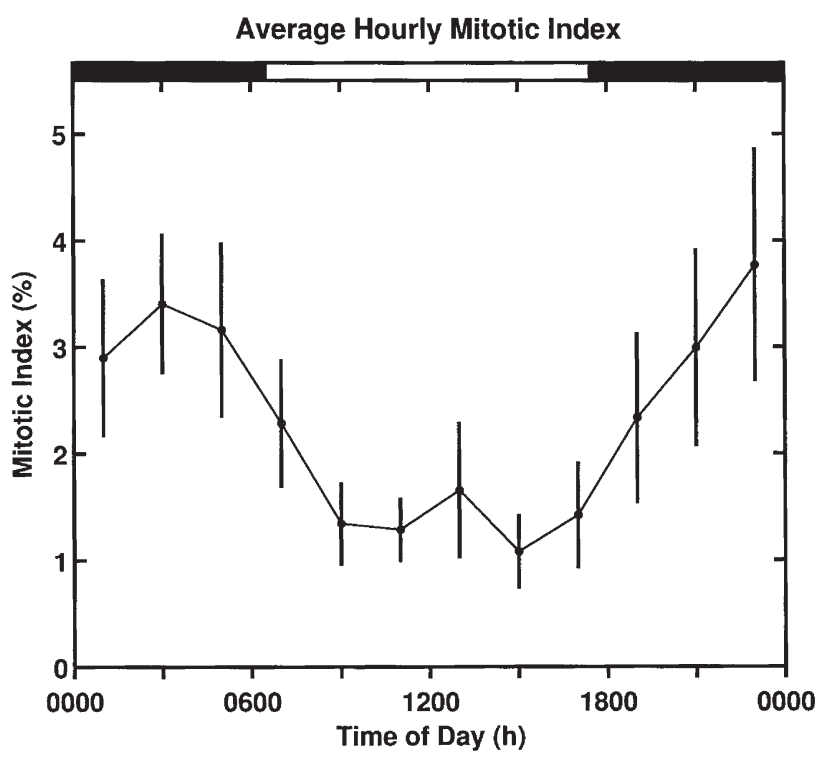

Fig. 2. The hourly mitotic index $(\mathrm{MI}) \pm 1$ standard error of the mean, $\sigma_{\mathrm{m}}=\mathrm{SD} / \sqrt{\mathrm{N}}$, where SD is the standard deviation of the original distribution and $\mathrm{N}$ is the sample size. Each data point represents the MI from that time of day averaged over all 14 days of the study 


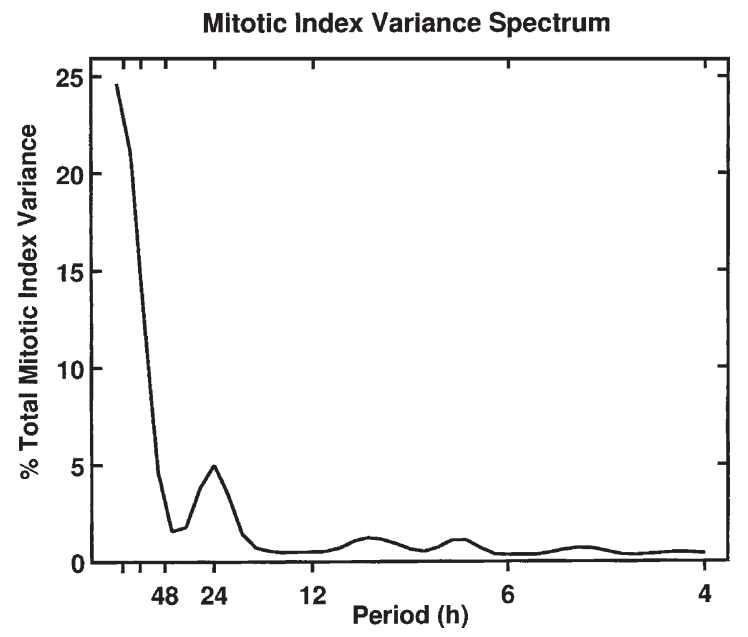

Fig. 3. Variance spectrum of the mitotic index time series. The 2 abscissa marks to the left of the $48 \mathrm{~h}$ mark represent the $96 \mathrm{~h}$ and $7 \mathrm{~d}$ period estimates, respectively

the main portion of the bloom was moving back and forth past the study site over the tidal cycle. This accounted for the large tidal oscillations in chl a concentration (Fig. 1). The progressive displacement of the bloom toward the study site was also evident as a general increase in chl $a>10 \mu \mathrm{g} \mathrm{l}^{-1}$ as salinities dropped below 20 psu.

At what chl a concentrations Heterocapsa triquetra began dominating the phytoplankton assemblage was determined by examining random samples for phyto-

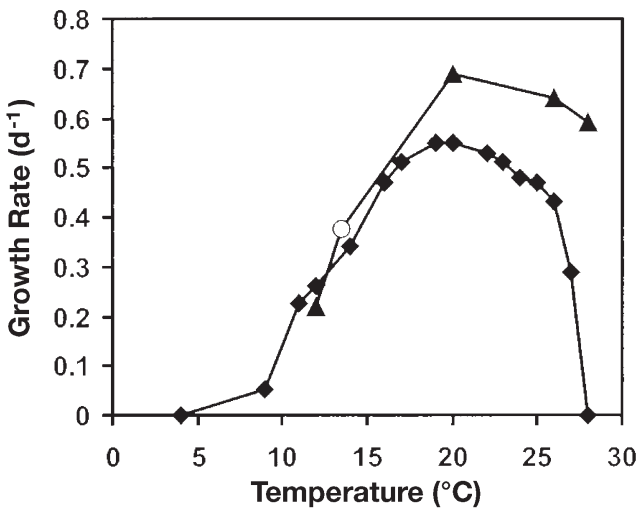

Fig. 4. Temperature versus maximal growth rate determined from various culture studies. Braarud \& Pappas 1951, Yamochi 1984, (0) Chang \& Carpenter 1988. A maximal growth rate of $0.7 \mathrm{~d}^{-1}$ was reported for a Heterocapsa triquetra clone isolated from a Massachusetts salt pond (Anderson \& Stolzenbach 1985). The specific temperature at which this growth rate was achieved was not reported. The maximal growth observed by Anderson \& Stolzenbach (1985) is consistent with the maximal rate of 1 division $\mathrm{d}^{-1}\left(0.69 \mathrm{~d}^{-1}\right)$ observed by Braarud \& Pappas (1951)

plankton composition during the 1983 study. H. triquetra cell numbers were found to be substantially lower

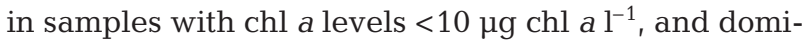
nant in samples where chl a levels were $>10 \mu \mathrm{g} \mathrm{l}^{-1}$. MI values were generally higher during the early part of the bloom in samples where $H$. triquetra was not yet the dominant species.

Table 1. Average water temperature $\left({ }^{\circ} \mathrm{C}\right)$, salinity (psu), and water column photosynthetically active radiation (PAR) (E m $\left.{ }^{-2} \mathrm{~d}^{-1}\right)$ from the 1983 time intensive study were determined by averaging the hourly values from 07:00 to 06:00 $\mathrm{h}$ the following morning. Maximal growth rates were estimated from data presented in Fig. 4. Daily growth rates were determined using either Eq. (1) or Eq. (2) with a $t_{\mathrm{d}}$ value of $8 \mathrm{~h}$ (McDuff \& Chisholm 1982)

\begin{tabular}{|c|c|c|c|c|c|c|}
\hline Date & $\begin{array}{c}\text { Average daily } \\
\text { water temperature } \\
\qquad\left({ }^{\circ} \mathrm{C}\right)\end{array}$ & $\begin{array}{l}\text { Average daily } \\
\text { salinity } \\
\text { (psu) }\end{array}$ & $\begin{array}{l}\text { Average daily } \\
\text { water column PAR } \\
\left(\mathrm{E} \mathrm{m}^{-2} \mathrm{~d}^{-1}\right)\end{array}$ & $\begin{array}{l}\text { Maximal growth rate } \\
\text { estimated from culture } \\
\text { studies }\left(\mathrm{d}^{-1}\right)\end{array}$ & $\begin{array}{l}\text { Minimal growth rate } \\
\text { estimated from Eq. }(1)^{\mathrm{a}} \\
\qquad\left(\mathrm{d}^{-1}\right)\end{array}$ & $\begin{array}{c}\text { Growth rate estimated } \\
\text { from Eq. }(2)^{\mathrm{b}} \\
t_{\mathrm{d}}=8 \mathrm{~h}\left(\mathrm{~d}^{-1}\right)\end{array}$ \\
\hline Jan 30 & 9.6 & 24.6 & 19.0 & 0.10 & 0.072 & 0.098 \\
\hline 31 & 10.5 & 25.3 & 34.6 & 0.17 & 0.140 & 0.21 \\
\hline Feb 1 & 11.4 & 24.9 & 35.4 & 0.23 & 0.091 & 0.17 \\
\hline 2 & 12.9 & 24.7 & 4.5 & 0.34 & 0.035 & 0.045 \\
\hline 3 & 12.0 & 23.8 & 19.8 & 0.27 & 0.031 & 0.028 \\
\hline 4 & 9.6 & 23.1 & 23.4 & 0.10 & 0.031 & 0.023 \\
\hline 5 & 8.4 & 21.7 & 28.6 & 0.046 & 0.043 & 0.025 \\
\hline 6 & 8.4 & 18.7 & 2.7 & 0.046 & 0.043 & 0.038 \\
\hline 7 & 8.3 & 17.2 & 14.5 & 0.045 & 0.049 & 0.048 \\
\hline 8 & 8.2 & 18.0 & 28.7 & 0.044 & 0.043 & 0.038 \\
\hline 9 & 9.0 & 18.1 & 30.3 & 0.052 & 0.077 & 0.105 \\
\hline 10 & 9.0 & 17.1 & 12.3 & 0.052 & 0.036 & 0.063 \\
\hline 11 & 9.1 & 15.2 & 9.5 & 0.065 & 0.020 & 0.016 \\
\hline 12 & 7.6 & 13.9 & 12.7 & 0.037 & 0.020 & 0.018 \\
\hline
\end{tabular}




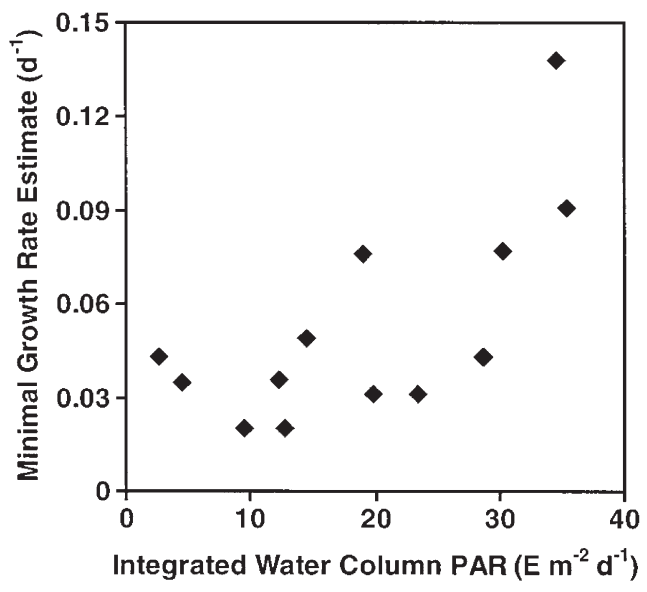

Fig. 5. Maximal daily growth rate $\left(\mathrm{d}^{-1}\right)$ as a function of the photosynthetically active radiation (PAR) $\left(\mathrm{E} \mathrm{m}^{-2} \mathrm{~d}^{-1}\right)$ integrated over the water column each day. Growth rate estimates were calculated using Eq. (1)

\section{Spatially intensive study (1998)}

The spatially intensive study showed that the major portion of the Heterocapsa triquetra bloom developed when light levels were at their minimum for the 3 mo study period and temperatures were declining to between 10 and $11^{\circ} \mathrm{C}$ (Fig. 7). Increases in the number of $H$. triquetra correlated well with changes in chl a levels

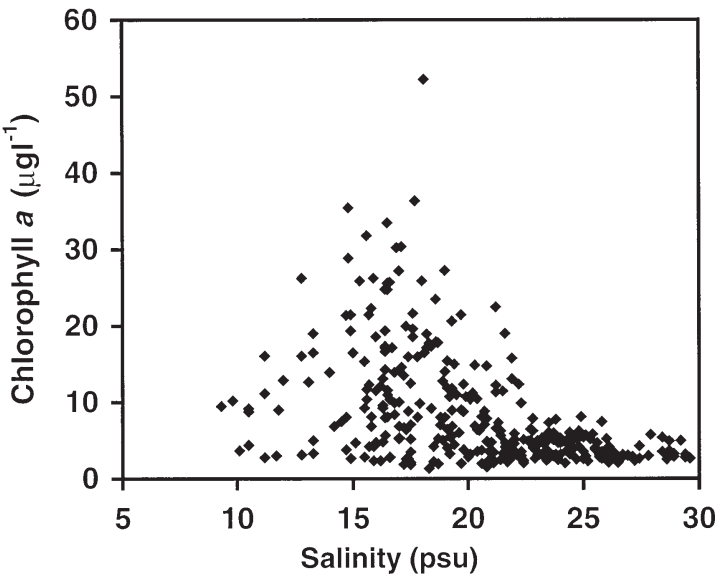

Fig. 6. Salinity (psu) versus chl a $\left(\mu g \mathrm{l}^{-1}\right)$. Samples with chl a levels $>10 \mathrm{~g} \mathrm{~g} \mathrm{l}^{-1}$ were dominated by Heterocapsa triquetra (Litaker 1986)

when chl a levels increased above $10 \mu \mathrm{g} \mathrm{l}^{-1}$. Chl a levels and $H$. triquetra cell numbers increased markedly as the Newport River flow rates rose above $5 \times 10^{6} \mathrm{~m}^{3}$ $\mathrm{wk}^{-1}$, and declined when flow rates exceeded $17 \times$ $10^{6} \mathrm{~m}^{3} \mathrm{wk}^{-1}$ due to dilution. The increase in chl $a$ and $H$. triquetra cell numbers also coincided with a substantial increase in inorganic $\mathrm{N}$ loading.

The salinity and temperature conditions, as well as chl a levels during early to mid-January 1998, were the

Table 2. Analysis of variance without replication. The amount of variance in the minimal daily growth rate (Eq. 1) presented in Table 1 accounted for by mean daily water temperature $\left({ }^{\circ} \mathrm{C}\right)$, salinity $(\mathrm{psu})$, and water column PAR $\left(\mathrm{E} \mathrm{m}^{-2} \mathrm{~d}^{-1}\right)$

\begin{tabular}{|c|c|c|c|c|c|c|c|}
\hline & & $\mathrm{df}$ & SS & MS & $\begin{array}{c}F \\
\text { value }\end{array}$ & $\begin{array}{c}\text { Probability } \\
>F\end{array}$ & $\begin{array}{c}\text { Adjusted } \\
\mathrm{R}^{2}\end{array}$ \\
\hline Light & $\begin{array}{l}\text { Model } \\
\text { Error } \\
\text { Corrected total }\end{array}$ & $\begin{array}{r}1 \\
12 \\
13\end{array}$ & $\begin{array}{l}0.00596 \\
0.00771 \\
0.01367\end{array}$ & $\begin{array}{l}0.00596 \\
0.00064257\end{array}$ & 9.27 & 0.0102 & 0.39 \\
\hline Salinity & $\begin{array}{l}\text { Model } \\
\text { Error } \\
\text { Corrected total }\end{array}$ & $\begin{array}{r}1 \\
12 \\
13\end{array}$ & $\begin{array}{l}0.00381 \\
0.00986 \\
0.01367\end{array}$ & $\begin{array}{l}0.00381 \\
0.00082170\end{array}$ & 4.63 & 0.0524 & 0.22 \\
\hline Temperature & $\begin{array}{l}\text { Model } \\
\text { Error } \\
\text { Corrected total }\end{array}$ & $\begin{array}{r}1 \\
12 \\
13\end{array}$ & $\begin{array}{l}0.00073514 \\
0.01293 \\
0.01367\end{array}$ & $\begin{array}{l}0.00073514 \\
0.00108\end{array}$ & 0.68 & 0.4250 & 0.025 \\
\hline Light and salinity & $\begin{array}{l}\text { Model } \\
\text { Error } \\
\text { Corrected total }\end{array}$ & $\begin{array}{r}2 \\
11 \\
13\end{array}$ & $\begin{array}{l}0.00711 \\
0.00655 \\
0.01367\end{array}$ & $\begin{array}{l}0.00356 \\
0.00059586\end{array}$ & 5.97 & 0.0176 & 0.43 \\
\hline With light and temperature & $\begin{array}{l}\text { Model } \\
\text { Error } \\
\text { Corrected total }\end{array}$ & $\begin{array}{r}2 \\
11 \\
13\end{array}$ & $\begin{array}{l}0.00647 \\
0.00720 \\
0.01367\end{array}$ & $\begin{array}{l}0.00324 \\
0.00065429\end{array}$ & 4.95 & 0.0294 & 0.38 \\
\hline Temperature and salinity & $\begin{array}{l}\text { Model } \\
\text { Error } \\
\text { Corrected total }\end{array}$ & $\begin{array}{r}2 \\
11 \\
13\end{array}$ & $\begin{array}{l}0.00474 \\
0.00893 \\
0.01367\end{array}$ & $\begin{array}{l}0.00237 \\
0.00081145\end{array}$ & 2.92 & 0.0960 & 0.23 \\
\hline Light, salinity, and temperature & $\begin{array}{l}\text { Model } \\
\text { Error } \\
\text { Corrected total }\end{array}$ & $\begin{array}{r}3 \\
10 \\
13\end{array}$ & $\begin{array}{l}0.00718 \\
0.00649 \\
0.01367\end{array}$ & $\begin{array}{l}0.00239 \\
0.00064922\end{array}$ & 3.68 & 0.0508 & 0.38 \\
\hline
\end{tabular}



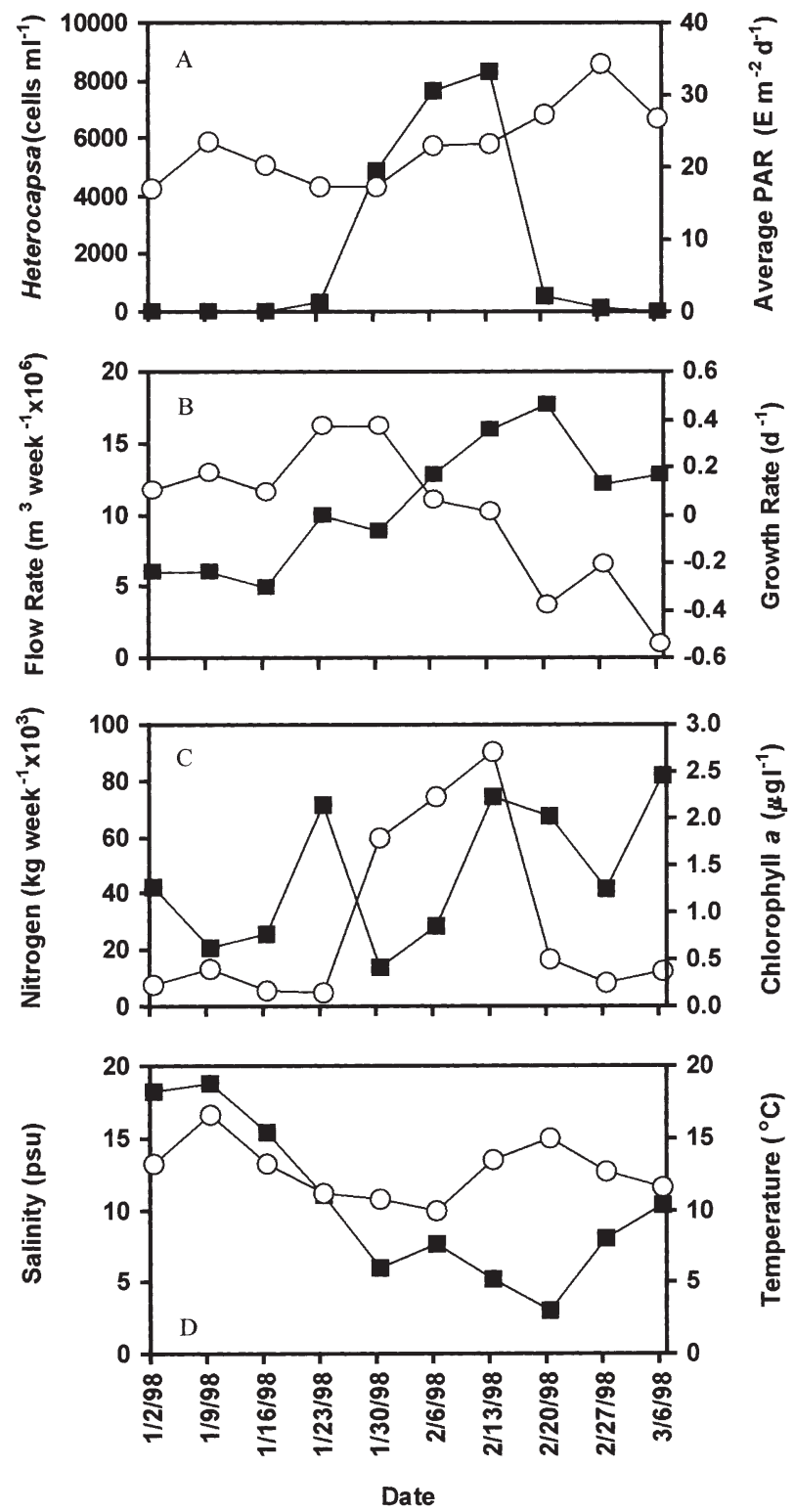

Fig. 7. (A) Average Heterocapsa triquetra cell densities (घ, cells $\mathrm{ml}^{-1}$ ) and average daily photosynthetically active radiation (PAR) for the week preceding each sampling date $\left(\mathrm{O}, \mathrm{E} \mathrm{m}^{-2}\right.$ $\mathrm{d}^{-1}$ ). (B) Estimated input of freshwater from the Newport River for the week preceding each sampling period $\left(\square, \mathrm{m}^{3} \mathrm{wk}^{-1} \times\right.$ $10^{6}$ ) and the estimated net growth rates calculated from the change in average $H$. triquetra cell densities from week to week during the study for the sites where significant numbers of $H$. triquetra were present $\left(0, \mathrm{~d}^{-1}\right)$. (C) The estimated inorganic nitrogen (nitrate + nitrite + ammonia) loading $(\mathbf{\square}, \mathrm{kg}$ $\mathrm{wk}^{-1} \times 10^{3}$ ) and the average chl a concentrations for each week of the study $\left(0, \mu \mathrm{g} \mathrm{l}^{-1}\right)$. Loading was calculated from the average weekly flow rate and the concentration of inorganic nitrogen measured in the freshwater portion of the Newport River. (D) The mean salinity for the stations used to calculate average $H$. triquetra densities ( $\square, \mathrm{psu})$ and mean temperature for the same sites for each sampling date $\left(\mathrm{O},{ }^{\circ} \mathrm{C}\right)$. Sections (A) and (D) demonstrate how light, temperature, and salinity increase and decrease in different patterns relative to each other, sometimes working in concert to favor growth and sometimes not most similar to those prevailing during the first $4 \mathrm{~d}$ of the February 1983 study when temperatures were also $>10^{\circ} \mathrm{C}$ (Figs. $1 \& 7$ ). The net growth rates of Heterocapsa triquetra estimated from week to week changes in mean cell density in early to mid-January 1998 ranged from 0.09 to $0.175 \mathrm{~d}^{-1}$ (Fig. 7). These rates are similar to the 0.04 to $0.14 \mathrm{~d}^{-1}$ in situ growth rates estimated from the MI data during the first $4 \mathrm{~d}$ of the 1983 study (Table 1).

In contrast, during the $2 \mathrm{wk}$ in the 1997 to 1998 spatially intensive study, when chl a levels increased

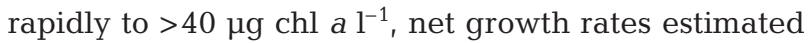
from changes in population densities from week to week were 0.369 to $0.373 \mathrm{~d}^{-1}$. These net growth rates are significantly higher than the 0.18 to $0.20 \mathrm{~d}^{-1}$ maximal growth rates estimated from culture studies of non-limited cells over this same temperature range (Figs. 4 \& 7). These results are consistent with physical or behavioral mechanisms that concentrate the cells in excess of growth, or with a mechanism that allows the cells in early bloom formation to grow at greater than expected rates.

\section{DISCUSSION}

The diel division pattern exhibited by Heterocapsa triquetra in the field during the time intensive study (1983) showed a nocturnal maximum and a diurnal minimum. This pattern agrees with that observed for $H$. triquetra clone 987 grown in the laboratory under a diel cycle of $14 \mathrm{~h}$ light $\left(15^{\circ} \mathrm{C}\right)$ and $10 \mathrm{~h}$ dark period $\left(11^{\circ} \mathrm{C}\right.$; Chang \& Carpenter 1988). Nocturnal cell division is characteristic of most dinoflagellates measured in the field (Doyle \& Poore 1974, Weiler \& Chisholm 1976, Heller 1977, Rivkin 1986) and in the laboratory (McMurray \& Hastings 1972, Nelson \& Brand 1979, Olson \& Chisholm 1983, Wheeler et al. 1983, Anita et al. 1990, Partensky et al. 1991). Theoretically, a diel division cycle allows maximization of light resources. Energy stored in the form of reduced carbon compounds is accumulated throughout the day when light is available, then subsequently utilized for cell division at night (Cohen \& Parnas 1976).

For the dinoflagellate species studied so far, diel synchrony is regulated by a cyclin-dependent kinase system that is entrained by the dawn dark:light (D/L) transition (Van Dolah \& Leighfield 1999). Changes in the timing of the D/L transition, and not the L/D transition, affect the progression into S-phase and ultimately when the nocturnal peak in $G_{2}+M$ cells occurs. The result of this diel entrainment is that maximal growth is limited to 1 division $\mathrm{d}^{-1}$ (McDuff \& Chisholm 1982). 


\section{Proportion of binucleate cells during high/low light periods}

Although most of the Heterocapsa triquetra cells observed in the 1983 study appeared to be entrained by the D/L entrainment, some of the cell divisions appeared to be phased differently. During 2 of the 3 high light periods, binucleate cells were observed throughout the afternoon, whereas during lower light periods binucleate cells were not observed (Figs. 1 \& 2 ). This increase in the number of binucleate cells during the afternoon could represent either a residual population of cells that failed to divide the previous night, or a subpopulation of cells that were actively dividing during the day. The methods used in this study cannot conclusively distinguish between these 2 possibilities, though the latter is more likely for the following reason: The major restriction point in the cell cycle of phototrophs is in G1. All the phototrophic cells studied to date move continuously from $\mathrm{S}$ through $\mathrm{M}$ phases after they have accumulated sufficient nutrients to exit G1 (Anita 1990, Gisselson et al. 1999). Thus, the binucleate cells observed in the late afternoon are more likely to be actively dividing and not cells that arrested in $\mathrm{M}$ phase the previous night.

Daytime division would be consistent with the hypothesis that when light levels are sufficiently high, certain cells will reach their upper size limit during the day and divide, despite the strong synchrony imposed by the dawn dark:light transition (Cohen \& Parnas 1976). There is precedence for this hypothesis. At least 1 species of Euglena is known to possess a mechanism that allows the cells to periodically escape the L:D synchrony and grow rapidly when conditions are favorable (Adams et al. 1984). Whether dinoflagellates have a similar growth release mechanism, and if so, how escaping L:D synchrony might effect bloom formation, has yet to be fully investigated (Van Dolah \& Leighfield 1999).

\section{Correlation of interday variations in daily growth rates with environmental factors}

Of the 3 factors examined in the 1983 time-intensive study (light, salinity, temperature), only changes in average daily PAR accounted for a significant ( $40 \%)$ portion of the interday variation in Heterocapsa triquetra growth (Figs. 1 \& 3, Table 2). The 2 culture studies done to date indicate that $H$. triquetra's growth saturates when cells are grown in a flask approximately $20 \mathrm{~cm}$ from a $100 \mathrm{~W}$ bulb (Barker 1935, Braarud \& Pappas 1951). Direct measurement of the PAR flux $20 \mathrm{~cm}$ from a $100 \mathrm{~W}$ bulb was found to be $28.7 \pm 0.3 \mu \mathrm{E}$ $\mathrm{m}^{-2} \mathrm{~s}^{-1}$ using a Licor ${ }^{\mathrm{TM}} 4 \pi$ collector. Over a $10 \mathrm{~h}$ day, a putatively growth-saturating flux of $28.7 \mu \mathrm{E} \mathrm{m} \mathrm{m}^{-2} \mathrm{~s}^{-1}$ equals approximately $1.1 \mathrm{E} \mathrm{m}^{-2} \mathrm{~d}^{-1}$. This means that there should have been enough light to saturate growth on even the lowest light day during the 1983 study (Table 1). The significant correlation between interday changes in light flux and MI, however, indicated that light levels from 2 to $4 \mathrm{E} \mathrm{m}^{-2} \mathrm{~d}^{-1}$ on cloudy days did reduce growth compared to sunny days when 28 to $30 \mathrm{E} \mathrm{m}^{-2} \mathrm{~d}^{-1}$ were available for growth. Because only $40 \%$ of the MI variation was accounted for by changes in light, it is unlikely that light limitation was severe (Fig. 1, Table 2). The apparent discrepancy between the laboratory and field estimates of the light levels needed to saturate $H$. triquetra growth could be accounted for if either the light fluxes in the laboratory studies were underestimated, or if the ambient light levels in the water column were overestimated. It should be noted, however, that despite the apparent discrepancies, both the field and laboratory data are consistent with $H$. triquetra requiring relatively low light levels to achieve maximal growth.

Salinity changes accounted for an additional $4 \%$ of the growth variation, whereas changes in mean daily temperature failed to correlate with growth rate changes in the field. The lack of a strong correlation between salinity and in situ growth rates can be accounted for by the fact that Heterocapsa triquetra has a broad salinity tolerance. Culture studies have shown that $H$. triquetra can achieve $>80 \%$ of maximal growth from 10 to $30 \mathrm{psu}$, with maximal growth occurring between 15 and 20 (Braarud \& Pappas 1951, Braarud 1961). Because most of the bloom was concentrated in a salinity zone of roughly 12 to 20 psu (Fig. 1), it is unlikely that salinity was significantly affecting growth during the time intensive study.

The lack of correlation between in situ growth and temperature, however, is surprising. Laboratory growth studies would predict that the temperature range encountered during the study should noticeably affect growth rates (Figs. 1 \& 4; Braarud \& Pappas 1951, Yamochi 1984, Anderson \& Stolzenbach 1985, Chang \& Carpenter 1988). A possible explanation for the lack of a discernible temperature effect is the complex set of interactions between temperature, salinity, light, and the nutritional status of the Heterocapsa triquetra population which was observed during the course of the time intensive study. Specifically, during the initial $3 \mathrm{~d}$ of the study, light levels were high and water temperatures steadily increased above $10^{\circ} \mathrm{C}$. This simultaneous increase in light and temperature favored growth and correlated with the highest MIs observed during the 14 d study. On Day 4, extremely low light conditions suppressed growth despite relatively high water temperatures favorable to increased growth. On Day 5, the situation reversed, with increased light levels favoring growth and rapidly declining water temperatures sup- 
pressing growth. From Days 6 to 14, the temperature changes were more regular from day to day. However, temperatures generally remained $<10^{\circ} \mathrm{C}$, severely limiting maximum potential growth rates (Figs. 1 \& 4). Accordingly, the MIs remained low with the only significant increase occurring on Days 10 and 11, when light levels were again relatively high (Fig. 1). This increase in the MI on Days 10 and 11, however, was smaller than that observed during the initial high light period, when temperatures were higher. After Day 11, both salinity and light declined, while water temperatures remained low. It was during this time that the MIs declined to the lowest levels observed during the study.

These observations are consistent with temperatures $<10^{\circ} \mathrm{C}$ having an ever greater role in damping the growth response of Heterocapsa triquetra to favorable increases in either nutrients or light. It should also be noted, that laboratory studies have consistently shown that the optimum temperature for $H$. triquetra growth is between 18 and $23^{\circ} \mathrm{C}$ (Braarud \& Pappas 1951, Carpenter 1973, Yamochi 1984), implying that the wintertime bloom of $H$. triquetra occurs despite suboptimal growth temperatures.

\section{Effect of different abiotic factors on the bloom initiation and development}

The generally declining growth rates observed during the 1983 time intensive study also coincide with the period when the Heterocapsa triquetra bloom population was increasing from $<10$ to $>30 \mu \mathrm{g} \mathrm{chl} \mathrm{al}^{-1}$. This apparent conflict can be accounted for by the hydrodynamics of the Newport River estuary and an artifact inherent in sampling from a fixed location. Runoff from the Newport River creates a mesohaline frontal zone somewhere in the upper or middle portion of the Newport River estuary. The location of the frontal zone is determined by the volume of runoff from the Newport River. During the formation of the 1998 bloom, $H$. triquetra net growth rates in the frontal zone, estimated from weekly changes in abundance, were much higher than could be accounted for by in situ growth (Figs. 4 \& 7, Table 1). This indicates that during bloom formation, $H$. triquetra cells were physically accumulating in this frontal zone in excess of what could be accounted for by growth.

During the initial phase of the 1983 time intensive study, runoff was lower than in the latter portion of the study. As a consequence, the mesohaline frontal zone containing the greater portion of the Heterocapsa triquetra population was located upstream of the fixed sampling site. Cells in the samples taken during the early part of the 1983 study, when chl a levels were $<10 \mu \mathrm{g} \mathrm{l}^{-1}$, were therefore from outside the main portion of the bloom. These cells were likely less nutrient- limited than the cells in the central portion of the bloom, where cell densities exceeded $\sim 1 \times 10^{3}$ cells $\mathrm{ml}^{-1}$. This assumption is supported by the mixotrophic feeding behavior exhibited by $H$. triquetra during the 1997 to 1998 spatially intensive study (Litaker et al. 2002). In that study, $H$. triquetra cells started feeding mixotrophically on other phytoplankton when $H$. triquetra chl a biomass exceeded $\sim 25 \mu \mathrm{g} \mathrm{l}^{-1}$. Laboratory studies have shown that $H$. triquetra grows exclusively as an autotroph when sufficient inorganic nutrients are available, but will resort to heterotrophy when N-or Plimited (Legrand et al. 1998). These findings imply that $H$. triquetra blooms in the Newport River, such as the one in 1983, are likely to become more nutrient-limited as they develop. Increasing nutrient limitation is also supported by residual inorganic $\mathrm{N}$ levels. Inorganic $\mathrm{N}$ levels are generally between 2 to $10 \mu \mathrm{M}$ in the Newport River during winter. As this relatively nutrientrich water enters the estuary, the nutrients are rapidly taken up by $H$. triquetra. Consequently, nutrient levels in the middle of the bloom are below the limits of detection, indicating nutrients are scarce relative to demand (Litaker et al. 1987). Hence, as runoff from the Newport River increased during the course of the 1983 study, the frontal zone containing the higher $H$. triquetra (chl a) biomass was gradually shifted closer and closer to the study site. This water mass contained slower-growing, more nutrient-limited cells. The lower MIs toward the middle and end of the 1983 time intensive study were therefore likely due to some degree of nutrient limitation, in addition to declining temperatures and transient low light levels.

Other late winter and early spring dinoflagellate blooms dominated by Heterocapsa triquetra have been observed to accumulate along frontal zones in the Chesapeake Bay. These blooms are large and can often be detected using satellite imagery (Tyler \& Stumpf 1989). H. triquetra is also known to behaviorally aggregate. It is a strong swimmer and vertically migrates to take advantage of nutriclines or 2-layered flow regimes, resulting in higher than expected population densities (Anderson \& Stolzenbach 1985, Kononen et al. 1999, 2000). A strong swimming ability also favors the accumulation of this species in convergence zones (Franks 1992, Kononen et al. 1999).

\section{Effect of interday variations in light on growth}

Carpenter \& Campbell's (1988) study of Synechococcus populations is the only other field study to follow the diel and interday changes in phytoplankton growth rates for $>1$ to $2 \mathrm{~d}$. In that study, interday changes in the growth of Synechococcus populations in the field also followed the interday variations in inci- 
dent light. This implies that phytoplankton populations frequently encounter transient light limitation associated with cloud cover. This transient light limitation is particularly important during the winter months along the coast of North Carolina, USA. At this time of the year, shorter day lengths reduce total daily irradiances approximately $40 \%$ relative to summer (Rosenberg 1981, Kenney 1985, Ramus 1985). Superimposed on this reduced incident radiation are 10 to 15 cloudy days a month where total daily incident PAR is reduced by an additional $40 \%$ or more. In contrast, equivalent light reductions generally occur only 2 to 5 days a month during the summer. This would imply that the transient low light levels associated with the passage of atmospheric frontal systems could greatly influence bloom formation.

Results of the spatially intensive study (1997 to 1998) instead indicate that Heterocapsa triquetra effectively adapts to these low light conditions. Indeed, the major increase in the $H$. triquetra population occurs during one of the lowest light weeks observed during the $3 \mathrm{mo}$ study and is consistent with the laboratory investigations that indicate $H$. triquetra can adapt to low light conditions (Fig. 7; Braruud \& Pappas 1951). These data imply that the interday variations in growth caused by transient light limitation were integrated through time and did not significantly affect the course of bloom formation. The start of the 1997 to 1998 bloom instead correlated with a large increase in inorganic $\mathrm{N}$ inputs to the estuary from the Newport River, not the changes in light, temperature, or salinity. Hence, nutrient inputs, rather than light, play the dominant role in $H$. triquetra bloom initiation.

Acknowledgements. We would like to thank Drs. H. Paerl and F. Van Dolah and 3 anonymous reviewers for their encouragement and constructive comments. J. Johnson and R. Marinshaw performed the multiple regression analysis. S. Varnam provided field assistance and counted the phytoplankton samples. B. Peierls and Dr. H. Paerl provided the 1998 PAR data from the weather station located at the Institute of Marine Sciences in Morehead City, North Carolina. M. Guo and B. Peierls ran the nutrient samples for the 1998 study. B. Butler provided editorial assistance. Funding for this study was provided by the NSF (Grant No. OCE-81-13328) and the National Center for Coastal Ocean Science, National Ocean Service, NOAA ECOHAB Contribution No. 43. References to trade names does not imply product endorsement by the National Ocean Service, NOAA. The US Government has the right to retain a nonexclusive royalty-free license in and to any copyright covering this paper. This paper is dedicated to Sue Kenney.

\section{LITERATURE CITED}

Adams KJ, Weiler CS, Edmunds LN (1984) Photoperiodic control of cell division in Euglena and Ceratium. In: Edmunds
LN (ed) Cell-cycle clocks. Marcel Dekker, New York, p 395-430

Anderson DM, Stolzenbach KD (1985) Selective retention of two dinoflagellates in a well-mixed estuarine embayment: the importance of diel vertical migration and surface avoidance. Mar Ecol Prog Ser 25:39-50

Anita AN, Carpenter EJ, Chang J (1990) Species-specific phytoplankton growth rates via diel DNA synthesis cycles. III. Accuracy of growth rate measurements in the dinoflagellate Procentrum mimimum. Mar Ecol Prog Ser 63: 273-279

Barker HA (1935) The culture and physiology of the marine dinoflagellates. Arch Mikrobiol 6:157-181

Braarud T (1961) Cultivation of marine organisms as a means of understanding environmental influences on populations. In: Sears M (ed) Oceanography. No. 67. American Association for the Advancement of Science, Washington, DC, p 271-298

Braarud T, Pappas I (1951) Experimental studies on the dinoflagellate Peridinium triquetrum (Ehrb.) Lebour Avhandlinger Utgitt Ar Det Norske Videnskaps-Akademi I Oslo 1. Mat. Naturv. Klasse 2:1-23

Carpenter EJ (1973) Brackish-water phytoplankton response to temperature elevation. Estuar Coast Mar Sci 1:37-44

Carpenter EJ, Campbell L (1988) Diel patterns of cell division and growth rates of Synechococcus spp. in Long Island Sound. Mar Ecol Prog Ser 47:179-183

Chang J, Carpenter EJ (1988) Species-specific phytoplankton growth rates via diel DNA synthesis cycles. II. DNA quantification and model verification in the dinoflagellate Heterocapsa triquetra. Mar Ecol Prog Ser 44:287-298

Cohen D, Parnas H (1976) An optimal policy for the metabolism of storage materials in unicellular algae. J Theor Biol 56:1-18

Doyle R, Poore RV (1974) Nutrient competition and division synchrony in phytoplankton. J Exp Mar Biol Ecol 14: 201-210

Franks PJS (1992) Sink or swim: accumulation of biomass at fronts. Mar Ecol Prog Ser 82:1-12

Gisselson LÅ, Granéli E, Carlsson P (1999) Using cell cycle analysis to estimate in situ growth rate of the dinoflagellate Dinophsis acuminata: drawbacks of the DNA quantification method. Mar Ecol Prog Ser 184:55-62

Guillard RRL (1973) Division rates. In: Stein JR (ed) Phycological methods. Cambridge University Press, Cambridge, p 289-311

Heller MD (1977) The phased division of the freshwater dinoflagellate Ceratium hirundinella and its use as a method of assessing growth in natural populations. Freshw Biol 7: 527-533

Hyle RA III (1976) Fishes of the Newport River estuary, North Carolina, their composition, seasonality and community structure, 1970-1972. PhD thesis, University of North Carolina

Jacquet S, Partensky F, Lennon JF, Vaulot D (2001) Diel patterns of growth and division in marine picoplankton in culture. J Phycol 37:357-369

Kenney BE (1985) Physiological bases of diurnal phyosynthesis in estuarine seaweeds. PhD thesis, Duke University, Durham, NC

Kim HG (1997) Recent harmful algal blooms and mitigation strategies in Korea. Ocean Res 19:185-192

Kononen K, Huttunen M, Kanoshina I, Laanemets J, Moisander P, Pavelson J (1999) Spatial and temporal variability of a dinoflagellate-cyanobacterium community under a complex hydrodynamical influence: a case study at the entrance to the Gulf of Finland. Mar Ecol Prog Ser 186:43-57 
Kononen K, Gentien P, Huttula T, Huttunen M, Laanemets J, Pavelson J, Stips A (2000) Deep chlorophyll maximum created by Heterocapsa triquetra Ehrenberg at the entrance to the Gulf Of Finland, Baltic Sea. 9th Int Conf Harmful Algal Blooms, 7-11 February 2000, Hobart, Tasmania, p 153 (Abstract)

Kuenzler EJ, Mullholland PJ, Ruley LA, Sniffen RP (1977) Water quality in North Carolina Coastal Plain streams and effects of channelization. WRRI Report No. 127, UNC Water Resources Research Institute, Raleigh, NC

Kuenzler EJ, Stanley DW, Koenings JP (1979) Nutrient kinetics of phytoplankton in the Pamlico River, North Carolina. WRRI Report No. 139, UNC Water Resources Research Institute, Raleigh, NC

Legrand C, Granéli E, Carlsson P (1998) Induced phagotrophy in the photosynthetic dinoflagellate Heterocapsa triquetra. Aquat Microb Ecol 15:65-75

Lindholm T, Nummelin C (1999) Red tide of the dinoflagellate Heterocapsa triquetra (Dinophyta) in a very-mixed coastal inlet. Hydrobiologia 393:245-251

Litaker W (1986) Dynamics of a well-mixed estuary. PhD thesis, Duke University, Durham, NC

Litaker W, Duke CS, Kenney BE, Ramus J (1987) Short-term environmental variability and phytoplankton abundances in a shallow tidal estuary. I. Winter and summer. Mar Biol 96:115-121

Litaker RW, Tester PA, Duke CS, Kenney BE, Pinckney JL, Ramus J (2002) Seasonal niche strategy of the bloomforming dinoflagellate Heterocapsa triquetra. Mar Ecol Prog Ser 232:45-62

Lund JWG, Kipling C, Le Cren ED (1958) The inverted microscope method of estimating algal numbers and the statistical basis of estimations by counting. Hydrobiologia 11: $143-170$

McDuff RE, Chisholm SW (1982) The calculation of in situ growth rates of phytoplankton populations from fractions of cells undergoing mitosis: a clarification. Limnol Oceanogr 27:783-788

McMurray L, Hastings JW (1972) No desynchronization among four circadian rhythms in unicellular alga Gonyaulax polyhedra. Science 175:1137-1139

Nelson DM, Brand LE (1979) Cell division periodicity in 13 species of marine phytoplankton on a light:dark cycle. J Phycol 15:67-75

Olson RJ, Chisholm SW (1983) Effects of photocycles and periodic ammonium supply on three marine phytoplankton species. I. Cell division patterns. J Phycol 19:522-528

Editorial responsibility: Yves Collos (Contributing Editor), Montpellier, France
Partensky F, Vaulot D (1991) Growth and cell cycle of two closely related red tide-forming dinoflagellates: Gymnodinium nagasakiense and G. cf. nagasaiense. J Phycol 27: 733-742

Pieterse F, Van der Post DC (1967) The pilchard of south west Africa (Sardinops ocellata): oceanographical conditions associated with red-tides and fish mortalities in the Walvis Bay region. Mar Res Lab Invest Rep (S-W Africa) 14:1-125

Ramus JR (1985) Light. In: Littler MM, Littler DS (eds) Handbook of phycological methods, Vol. 4: Ecological field methods. Cambridge Univ Press, New York, p 33-52

Riley GA (1957) Phytoplankton of the north central Sargasso Sea. Limnol Oceanogr 2:252-270

Rivkin RA (1986) Incorporation of tritiated thymidine by eucaryotic microalgae. J Phycol 22:193-198

Rosenberg GG (1981) Ecological growth strategies in the seaweeds Gracilaria foliifera (Rhodophyceae) and Ulva sp. (Chlorophyceae). PhD thesis, Yale University, New Haven, CT

Sokal RR, Rohlf FJ (1994) Biometry: the principles and practice of statistics in biological research. WH Freeman, New York

Stanley DW, Daniel DA (1985) Seasonal phytoplankton density and biomass changes in South Creek, North Carolina. J Elisha Mitchell Sci Soc 101:130-141

Tyler MA, Stumpf RP (1989) Feasibility of using satellites for detection of kinetics of small phytoplankton blooms in estuaries: tidal and migrational effects. Remote Sens Environ 27:233-250

Van Dolah FM, Leighfield TA (1999) Diel phasing of the cellcycle in the Florida red tide dinoflagellate Gymnodinium breve. J Phycol 35:1401-1411

Weiler CS, Chisholm SW (1976) Phased cell division in natural populations of marine dinoflagellates from shipboard cultures. J Exp Mar Biol Ecol 25:239-247

Wheeler PA, Olson RJ, Chisholm SW (1983) Effect of photocycles and periodic ammonium supply on three marine phytoplankton species. II. Ammonium uptake and assimilation. J Phycol 19:528-533

Whiteley AS, Burkill PS, Sleigh MA (1993) Rapid method for cell cycle analysis in a predatory marine dinoflagellate. Cytometry 14:909-915

Yamochi S (1984) Effects of temperature on the growth of six species of red-tide flagellates occurring in Osaka Bay. Bull Plankton Soc Jpn 31:15-22

Yentsch CS, Menzel DW (1963) A method for the determination of phytoplankton chlorophyll and phaeophytin by fluorescence. Deep-Sea Res 10:221-231

Submitted: Augst 13,2000; Accepted: August 20, 2001 Proofs received from author(s): April 10, 2002 